\title{
Exploration of Innovative Talent Training Path in English Teaching Reform of Application-oriented Universities
}

\author{
Fang Chen \\ Nanchang Institute of Science and Technology, Nanchang Jiangxi, 330000, China
}

Key words: Application-based, University English, Teaching, Talent training.

\begin{abstract}
University English teaching reform deepens continuously. English teaching of application-based universities is also faced with large social demand. As university teaching disciplines upgrade continuously, talent training mode in which innovative teaching method is applied not just adapts social talent development needs, but also cultivates innovative and professional inter-disciplinary talents for the society. This paper ponders over development trend of innovative talent training and training status in Chinese English teaching reform, analyzes teaching mode in the new period and proposes good innovation paths to improve English teaching level of application-oriented universities.
\end{abstract}

\section{Introduction}

English teaching of application-oriented universities improves people's development level in current world development and offers favorable application conditions for people. Inter-disciplinary talent training can not merely conform to social development demand, but also provide more applied talents for enterprises in current social development. Thus, as social and economic level keeps improving, the application of new innovation paths to train innovative and applied talents becomes a new development trend.

\section{Development status}

Development status: firstly, foreign applied talents show diversified training modes. Besides, due to the influence of old education idea in China, university teaching trends to be consistent. Secondly, practical teaching content is disconnected with social development. English is a second language in China's foreign language teaching. Learning environment in China is different from that in other countries. Some inland regions have no high degree of internationalization, and English application level in work is not high enough. Meanwhile, the time for English communication is less in schools, streets and stores. This reduces effective formation of learning environment and also makes students lose the interest in learning English. Since application-oriented universities are influenced by enrollment system, students' levels differ a lot. Thus, students' English levels also differ a lot. In English teaching, some teaching advantages and language formation suffer many obstacles. Thus, different teaching paths form.

\section{Realization of teaching mode in new period}

\section{Definition of teaching thought}

Rational teaching thought should be defined, and important function and significance of English should be firmed. Language application is not just a kind of disciplinary knowledge, but also a skill. 
Thus, correct teaching concept should form in the new period. Universities should not just actively determine teaching concept with new teaching nature and new teaching direction, but also regards spoken language communication as the chief problem to be thought in English teaching. Moreover, students should understand the importance of English and deem language as the main purpose of skill improvement so as to provide favorable approach for practical English application.

\section{Selection of teaching content}

Teaching content should be chosen rationally. There have been many university English teaching materials in recent years, and each specialty has different features. But, English materials used by universities lack strict operability, and it is hard to form unity between teaching and learning in classroom. Regardless of purchased materials or the materials prepared by English teachers, the course standards are decided by strict problems. For course material selection, the materials should focus on teaching content and grasp certain teaching procedure. Meanwhile, it is required to rationally choose teaching content in different period. During selecting teaching content, first of all, content authenticity and environment authenticity should be ensured. Besides, the materials should be feasible and scientific according to different cultural contents and students; cultural differences so as to motivate students' leaning interest.

\section{Enhancement of process assessment}

It is required to promote teaching content standardization and enhance assessment process. The teaching of application-oriented universities mainly aims to train students' application ability and to effectively improve students' application level. The assessment purpose is not to simply test students' knowledge mastery situation, but to facilitate the combination mode between teaching and learning and improve students' ability to acquire knowledge information so as to offer a new teaching channel for students to gain new knowledge. In addition, teachers should master rational knowledge construction system, guide teaching in the examination form and promote completeness of knowledge construction ${ }^{[1]}$.

\section{Optimization of traditional teaching}

It is required to improve traditional teaching mode and develop student-oriented teaching concept. English teaching in universities has certain rules. Providing good teaching method for students becomes a problem which should be mainly thought on the new period. In traditional teaching classroom, difficult knowledge points and teaching methods are mainly taught, but this cannot achieve certain teaching significance. Some problems cannot be well solved. Thus, university teachers should not merely guide students to master contents and the communication relationship existing in the contents, but also cognize existing cognition content and relevant elements. In addition, teachers should analyze the complexity of English teaching materials, regard students as subjects in learning, promote them to rationally construct knowledge and offer help for students. In classroom teaching in the new period, it is very significant to regard students as the subjects, and improve their application ability and vocational development ability.

\section{Innovative talent training path in English teaching reform of application-oriented universities}

\section{To enhance teacher training force}

During training applied English talents, it is most necessary to enhance teacher training force. During comprehensive development of English of application-oriented universities, it is required not just to cultivate the talents who master foreign language skills, but also to enhance teacher training force and make them apply their specialty and achieve application-oriented teaching. Thus, it is required to train English teachers, promote their teaching level. Firstly, some foreign language teachers can be mainly cultivated in school teaching training and they are required to give full play to their 
professional level in teaching ${ }^{[2]}$. Secondly, English teachers' reaches in each field should be expanded, and their specialty characteristics should be fully exerted. This can improve teachers' knowledge level and facilitate them to effectively train applied talents.

\section{To promote the relationship between foreign language popularization and industrial talent training}

Under the situation where English teaching of application-oriented universities deepens continuously, its development should be promoted with new teaching modes. Besides, the relationship between foreign language popularization and industrial talent training should be facilitated, and their mutual promotion and cooperative teaching should be achieved. Handling well English teaching popularization and achieving professional talent training mode play a great role in current teaching field. University English teaching mainly covers foreign language specialty, public foreign language and professional foreign language. Thus, these aspects should form an integral teaching mode so as to cultivate more professional talents with higher level. This can not just conforms to English teaching reform demand of application-oriented universities, but also meet potential demand of students of each discipline for foreign language teaching. Therefore, combination of each aspect of English teaching achieves stable promotion of each factor of foreign language teaching and deep study of language teaching so as to train professional English talents.

\section{To achieve talent training innovation}

During training English talents of application-oriented universities, training strategy innovation should be realized. Under the new path, new teaching path should be established for English teaching of application-oriented universities, so as to facilitate new mode of talent training in teaching field. For example, for public foreign language specialty, it mainly cultivates quality-based expanding teaching related to basic expanding courses of foreign language and international expanding courses of foreign language. These courses as the sole teaching standard can promote English teachers; teaching expertise and make teaching exerts its maximum advantage. Under such new teaching mode, faster teaching speed is provided for discipline teaching of universities, and solid discipline mastery is achieved. Meanwhile, professional teachers are cultivated for universities. Thus, new innovative talents and practical talents continuously form in teaching field.

\section{Extend bilingual course}

It is required to enhance extension of bilingual course and construct test point of bilingual course ${ }^{[3]}$. In a sense, bilingual course belongs to professional foreign language teaching field. But in current university English teaching, it is seriously ignored. English teaching level is insufficient, and teaching expertise is also insufficient. Improvement of teaching level and formation of teaching expertise are indispensable. The two aspects promote each other. Besides, the combination mode of the two can offer beneficial condition for constructing bilingual course teaching. Hence, first of all, proper pilot teaching work should be constructed during extending bilingual course teaching. It is mainly constructed according to bilingual course teaching rules and main methods of bilingual course teaching so as to promote preliminary construction of pilot teaching of bilingual course. Then, it is required to facilitate continuous popularization and active extension of bilingual course. In this way, students can not merely achieve real teaching significance in bilingual course teaching, but also positively welcome it. This can promote bilingual course teaching to achieve greater value in application and learning process.

\section{Diversified assessment mechanism}

During teaching in the new period, diversified assessment mechanism should be established, except applied talent training mechanism. Diversified and flexible assessment mode should be established for students' learning process according to English talent training objective of application-oriented universities. In the evaluation process, first of all, students' language competence, cross-cultural 
teaching and communication ability are evaluated according to teaching content. Then, the evaluation is based on students' learning method and learning process. It is required to promote effective combination of final teaching and process teaching and achieve dynamic and comprehensive evaluation process $^{[4]}$. Students' learning evaluation is not just reflected in test scores, but also reflected in learning process, skill level, knowledge learning and ability. In the evaluation process, students' daily learning should be assessed, such as class attendance, classroom performance and autonomous learning ability. For students' skill assessment, their English skills and professional English knowledge mastery are mainly assessed. Periodic assessment mainly aims at the task completed in a period and especially practical teaching. In the whole teaching activity, students; learning confidence is stimulated in the form of increasing scores in the later examination. Therefore, diversified learning evaluation mechanism can not just encourage students' autonomous learning ability, but also enhance their learning quality.

\section{To facilitate the relationship between general education and top talent training}

It is required to facilitate relationship between general education and top talent training. Generally, hierarchical teaching mode is implemented in university English teaching, or special class is set according to students' learning features. Although such hierarchical teaching mode can improve students' scores, the relations among each hierarchy should be promoted, and students' learning needs should be met continuously ${ }^{[5]}$. In teaching, the principal factor restricting language teaching is students' difference change, some English teachers should not just promote their teaching expertise, but also give full play to some teaching advantages of universities. In hierarchical teaching field, students' professional level should improve on the whole, and some professional English courses should be added to improve students' English study on the whole. Secondly, the relations among each hierarchy should be handled well and mutual integrative development should be enhanced so as to make applied talent training of universities exert the optimal effect. Under the new teaching reform system, applied teaching talents should be cultivated to meet international development demand. Universities should not just make students form lifelong learning idea, but also promote instrumental and humanistic teaching of English on the basis of meeting students' learning needs. Applied teachers of universities should enhance training of students' language competence and stick to people-oriented teaching concept. In this way, students' thinking ability for English expression can be cultivated, and English teaching can serve as the dominant teaching content.

\section{Conclusion}

As global economic integration advances continuously, communication among people becomes wider and wider. In particular, English becomes a discipline people need to master. Hence, this paper analyzes English teaching of English universities, expounds the new mode in the new period and proposes countermeasures to facilitate active training of applied talents.

\section{References}

[1] Chen Hongwen, Immersive teaching based on associated content: analysis of talent training mode of business English specialty. Foreign Language and Literature (Journal of Sichuan International Studies University), 2013,29(4):158-160.

[2] Guan Zhenbin, Fang Xiaomei, Thought on English talent training objective under application transformation situation of universities. Journal of Hubei University of Education, 2015,32(1):93-95.

[3] Zhu Nan, Feasibility of "internet + education" in business English talent training of application-oriented universities. English Square (III), 2015(8):112-113. 
[4] Zhou Yi, Analysis of “ecological” business document teaching under applied business English talent training idea. Survey of Education (I), 2016,5(1):98-100.

[5] Yang Lu, English teaching talent training path of application-oriented universities - combination of work and learning. Heilongjiang Researches on Higher Education, 2013,31(12):159-161. 